\title{
Some plants used in the treatment of leprosy in Africa
}

\author{
N NWUDE \& OMOTAYO O EBONG \\ Dept. of Physiology \& Pharmacology, Faculty of Veterinary \\ Medicine, Ahmadu Bello University, Zaria, Nigeria
}

Received for publication 12 August 1979

Summary Thirty-four speices of plants reported used in the treatment of leprosy in Africa are reviewed. The botanical and vernacular names, localities and comments on the plants are given. The importance of research into herbal medicine to establish the efficacy and toxicity of plants used is discussed.

\section{Introduction}

For centuries herbal medicine, a branch of traditional medicine, played an important role in the treatment of diseases world-wide. However, traditional medicine has almost completely been replaced by modern orthodox medicine in industrialized countries, while in the developing countries of Africa and Asia it still remains the dominant form of health care, especially in rural areas. It is often the only form of treatment sort and is sometimes regarded as superior to orthodox medicine in some respects. In some cases it is the last resort sort by Patients who feel no substantial relief after attending a clinic or hospital, particularly in cases of chronic sickness.

Leprosy is one of the most dreaded diseases and almost all branches of traditional medicine including psychotherapy, therapeutic occultism and herbal medicine have been employed in its treatment. In addition, social ostracism was practised. However, herbal medicine has played the most important role in the treatment of leprosy. Even in orthodox medicine plant extracts played an important role in the treatment of leprosy. Chaulmoogra oil (from Hydnocarpus $s p p$.) dominated the treatment until the advent of sulphones.

The developing tropical countries with their luxuriant and varied flora and long practice of traditional medicine have accumulated a mass of folk medicine that needs urgent investigation. This is because those versed in traditional medicine are getting fewer and fewer as the younger generation embraces modern education. A few of the plants have been studied and their action on animal body and the rationale for their use by traditional healers confirmed or $0305-7518 / 80 / 010011+18 \$ 01.00$ @ 1980 British Leprosy Relief Association 
Table 1. Some plants used in the treatment of leprosy in Africa

\begin{tabular}{|c|c|c|c|c|}
\hline Plants & Vernacular names & Locality & Comments & References \\
\hline $\begin{array}{l}\text { Acacia arabica, } \\
\text { Willd. }\end{array}$ & $\begin{array}{l}\text { Arab (E. Sudan): } \\
\text { 'sunt' }\end{array}$ & East Sudan & $\begin{array}{l}\text { A decoction } \\
\text { of the pods is drunk and } \\
\text { rubbed on the skin }\end{array}$ & Dalziel $(1937)^{1}$ \\
\hline $\begin{array}{l}\text { Acacia Seyal, } \\
\text { Del. }\end{array}$ & Hausa: 'dushe' & Nigeria & $\begin{array}{l}\text { Decoction } \\
\text { of the bark is used }\end{array}$ & Dalziel $(1937)^{1}$ \\
\hline $\begin{array}{l}\text { Acanthospermum } \\
\text { hispidium } \\
\text { DC. }\end{array}$ & Twi: 'sraha nsoe' & Ghana & & Dalziel $(1937)^{1}$ \\
\hline $\begin{array}{l}\text { Aframomum mala, } \\
\text { KSchum }\end{array}$ & Kimbunga: 'mitwewe' & Tanzania & $\begin{array}{l}\text { Decoction of the root is } \\
\text { taken }\end{array}$ & Haerdi $(1964)^{2}$ \\
\hline $\begin{array}{l}\text { Bauhinia rufescens, } \\
\text { Lam }\end{array}$ & Bamb: 'sifile' & Sudan & $\begin{array}{l}\text { The bark or root is made } \\
\text { into an extract, boiled } \\
\text { and drunk }\end{array}$ & Dalziel $(1937)^{1}$ \\
\hline $\begin{array}{l}\text { Bauhinia Thonningii } \\
\text { Schum. }\end{array}$ & $\begin{array}{l}\text { Hausa: 'Kalgo' } \\
\text { Yoruba: 'abafe' } \\
\text { Ibo: 'Okpo-atu' }\end{array}$ & Nigeria & $\begin{array}{c}\text { The bark, root or leaf } \\
\text { may be chewed }\end{array}$ & Dalziel $(1937)^{1}$ \\
\hline $\begin{array}{l}\text { Caloncoba } \\
\text { Welwitschii }\end{array}$ & Mpomgwe: ‘ebongo’ & Gabon & $\begin{array}{l}\text { The seeds are very rich in } \\
\text { chaulmoogra oil and } \\
\text { are very much valued } \\
\text { for treatment of leprosy }\end{array}$ & $\begin{array}{l}\text { Raponda-Walker } \\
\text { and Sillans }(1961)^{3}\end{array}$ \\
\hline $\begin{array}{l}\text { Caloncoba } \\
\text { glauca Gilg }\end{array}$ & Mpomgwe: 'ebongo' & Gabon & $\begin{array}{l}\text { The seeds contain Chaulmoogra } \\
\text { oil suitable for treatment } \\
\text { of leprosy }\end{array}$ & $\begin{array}{l}\text { Raponda-Walker } \\
\text { and Sillans }(1961)^{3}\end{array}$ \\
\hline $\begin{array}{l}\text { Capparis } \\
\text { tomentosa, } \\
\quad \text { Lam. }\end{array}$ & Hausa: 'haujeri' & Nigeria & The bark and root are used & $\begin{array}{l}\text { Watt and Breyer- } \\
\text { Brandwijk }(1962)^{4}\end{array}$ \\
\hline $\begin{array}{l}\text { Butyrospermum parkii, } \\
\text { Kotschy }\end{array}$ & & French Guinea & The crushed bark is used & Dalziel $(1937)^{1}$ \\
\hline
\end{tabular}


Cassia siberiana,

DC.

Clematis hirsuta,

Guill: and Perrq.

Commiphora spp.

Cordia goetzei,

Gurke.

Crinum giganteum,

Andr.

Culcasia spp.

Cyrtanthus obliquus,

Ait.

Dichrostachys glomerata, Choir.

Drymaria Cordata

Willd.

Eleusine coracana,

Asch. \& Gr.

Erythrina sacleuxii,

Hua.

Kihehe: 'muhemi'

Kimbunga:

'mgongolokashuka'

Galoa: 'Owavi-indjina'

Ficus lecardii,

Warb.

Hausa; 'baure'

Yoruba: 'aba'

Ibo: 'akakaru'
Congo

Gabon

South Africa

East Sudan

Gabon

South Africa

Roots are used in

Dalzie

combination with other

$(1937)^{1}$

drugs

Used internally in

Dalziel (1937) ${ }^{1}$

Leprosy

Decoction of the root is drunk and the fruit juice rubbed on the skin

The juice of the leaves and a decoction of the root are drunk. The ash from the leaves is rubbed on the skin

The bulb is used

The leaves are effective against leprosy

The root is used

Decoction of the root is used

This herb is used in treatment of leprosy

Used with Plumago zeylanica as a remedy for leprosy

Tanzania Decoction of the root and that of Rubia cordifolia is drunk for months

Benue-Bauchi, Nigeria
Haerdi (1964) $)^{2}$

Haerdi (1964)

Watt and BreyerBrandwijk (1962) ${ }^{4}$

Raponda-Walker and Sillans $(1961)^{3}$

Watt and BreyerBrandwijk (1962) ${ }^{4}$

Dalziel (1937) ${ }^{1}$

Raponda-Walker and Sillans $(1961)^{3}$

Watt and Breyer-

Brandwijk (1962) ${ }^{4}$

Haerdi (1964) ${ }^{2}$

Dalziel (1937) 


\begin{tabular}{|c|c|c|c|c|}
\hline Plants & Vernacular names & Locality & Comments & References \\
\hline $\begin{array}{l}\text { Guiera senegalensis } \\
\text { Lam. }\end{array}$ & $\begin{array}{l}\text { Hausa; 'Sabara' } \\
\text { Fulani: 'geloki' }\end{array}$ & Sokoto, Nigeria & $\begin{array}{l}\text { Plant has special reputation } \\
\text { as a preventive of leprosy. } \\
\text { A cold decoction is drunk } \\
\text { every morning and evening. } \\
\text { In particular it is given to } \\
\text { new-born child and the child } \\
\text { of a leper or where there is } \\
\text { suspicion of hereditary taint } \\
\text { or early symptom }\end{array}$ & Dalziel $(1937)^{1}$ \\
\hline $\begin{array}{l}\text { Hilleria latifolia, } \\
\quad \text { H. Watt. }\end{array}$ & Twi: 'anafranaku' & $\begin{array}{l}\text { Ashanti, } \\
\text { Ghana }\end{array}$ & The plant is boiled and drunk & Dalziel $(1937)^{1}$ \\
\hline $\begin{array}{l}\text { Lasiosiphon kraussianus, } \\
\text { Meisn. }\end{array}$ & Hausa: 'tururibi' & & $\begin{array}{l}\text { Methanol extract of the root } \\
\text { was reported to have a } \\
\text { therapeutic action in leprosy }\end{array}$ & Tubery $(1968)^{5}$ \\
\hline $\begin{array}{l}\text { Lonchocarpus cyanescens, } \\
\text { Benth. }\end{array}$ & Me: 'njala wai' & Sierra-Leone & The root is used & Dalziel (1937) \\
\hline $\begin{array}{l}\text { Ocimum viride } \\
\text { Willd. }\end{array}$ & Mpongwe: 'nunduwele' & Gabon & The leaves are used & $\begin{array}{l}\text { Raponda-Walker } \\
\text { and Sillans }(1961)^{3}\end{array}$ \\
\hline $\begin{array}{l}\text { Parkia filicoides, } \\
\text { Welw. }\end{array}$ & $\begin{array}{l}\text { Hausa: 'dorawa' } \\
\text { Yoruba: 'Irugba' } \\
\text { Ibo: 'agirili-Igala' }\end{array}$ & Nigeria & $\begin{array}{l}\text { The young unexpanded } \\
\text { flower buds are sometimes } \\
\text { used as a medicine or } \\
\text { preventive }\end{array}$ & Dalziel $(1937)^{1}$ \\
\hline $\begin{array}{l}\text { Pentaclethra } \\
\text { macrophylla, } \\
\text { Benth. }\end{array}$ & Basa: 'blay-bu' & Liberia & $\begin{array}{l}\text { Wood is sometimes boiled with } \\
\text { other native drugs and used. } \\
\text { The pounded bark is applied } \\
\text { locally }\end{array}$ & Dalziel (1937)I \\
\hline $\begin{array}{l}\text { Plumbago zeylanica, } \\
\text { Linn. }\end{array}$ & & South Africa & $\begin{array}{l}\text { The powdered root is used } \\
\text { internally and locally with } \\
\text { Eleusine corocane }\end{array}$ & $\begin{array}{l}\text { Watt and Breyer- } \\
\text { Brandwijk }(1962)^{4}\end{array}$ \\
\hline
\end{tabular}




\section{Rubia cordifolia,}

$\mathrm{L}$

Kipogoro: 'muswania'

Tanzania

\section{Sapium grahamii,}

Prain

Hausa: 'yazawa'

Nigeria

Stereospermum

kunthianum,

Cham.

Tamarindus indica,

L.

Tamarindus indica,

L.
Kimbunga:

'mkokonanguruwe'

Tanzania

Nigeria

Kiswashili: 'mkwaju'
The juice of the leaf is

rubbed on the skin.

Decoction of the root

together with that of

Erythrina sacleuxii is

boiled and drunk

The leaves and roots with the leaves of Loranthus

spp. found on Vitex

cienkowskii and shea

butter tree are used.

Decoction of the root and

bark is drunk together

with that of Tamarindus indica. Also the ash from

the bark and root is mixed

with oil and rubbed on the

skin lesions

An extract is made of the bark and husk of the pods of

Tamarindus indica and the

leaves and bark of Diospyros mespiliformis and drunk

Decoction is made from the root and bark along with

those of Stereospermum

kunthianum and drunk
Haerdi $(1964)^{2}$

Dalziel (1937) ${ }^{1}$

Haerdi $(1964)^{2}$

Dalziel (1937) 
rejected but a great majority has not been investigated, even though there is increased awareness of the role of traditional health care in the developing countries.

The therapy of leprosy is not yet satisfactory and it may be that traditional herbal remedies would have something to offer for effective treatment or a model on which chemists can work and improve upon.

This review of some plants used in the treatment of leprosy in Africa (Table 1) is presented with the hope that it would stimulate research interests to establish their efficacy or otherwise in the treatment of leprosy.

\section{Discussion}

The importance of investigations into traditional herbal medicine cannot be overemphasized. A number of drugs used in modern orthodox medicine originated from folk medicine. For instance, d-tubocurarine a muscle relaxant used in modern orthodox medicine was isolated from curare which was used as arrow poison by the South American Indians (Goodman and Gilman, 1975). ${ }^{6}$ Quinine was discovered from the bark of the Cinchoma tree which was also used in South America for the treatment of fever. Until some decades ago Cinchoma alkaloids formed the sole chemotherapeutic agents for specific treatment of malaria. Rauwolfia was used by the ancient Hindus for the treatment of hypertension, insomnia and insanity. On investigation, reserpin was isolated and is a valuable antihypertensive agent as well as tranquilizer. The ancient Hindus also used Belladona plants from which atropine and scopolamine were isolated and used to present day (Goodman and Gilman, 1975). ${ }^{6}$ Ipecacuanha was used by natives of Brazil in the treatment of diarrhoeas. It was used as such in modern orthodox medicine for the treatment of amoebiasis, though its use is limited because it causes severe gastrointestinal irritation, nausea and vomiting, but its emetic property is now used to induce vomiting in case of orally ingested drugs. Cascara Sagrada obtained from the bark of Rhamus purshiana was used by Indians of California as a carthartic and is still used as such in modern orthodox medicine.

All these examples point to the fact that investigations of folk remedies could lead to the discovery of potent drugs, not only for the diseases for which they were originally used by the natives but also for diseases unknown to the natives. The fact that plants like Calonchoba welwitschi and Calonchoba glauca used by the natives in treatment of leprosy contain chaulmoogra oil (RapondaWalker and Sillans, 1961) ${ }^{3}$ shows that some of the herbal treatment would be effective.

However, it is not only important to investigate the herbals to establish their efficacy but it is also equally important that their toxic effects be investigated. In the past few years, there have been a number of reports of poisoning in humans after administration of herbs. In Jamaica, venoocculsive liver disease 
in children was traced back to consumption of 'bush teas' which are infusions of various plants including Senecio and Crotalaria spp. (Schoental, 1963). ${ }^{7}$ There was a decrease in the incidence of this disease following a successful educational campaign against 'bush teas' (Schoental, 1972). ${ }^{8}$ Schoental and Coady $(1968)^{9}$ reported on the hepatoxicity of a number of Ethiopian and East African medicinal plants, including Senecio, Crotalaria, Heliotropium and Cynoglossum species. Liver cirrhosis and tumours were produced in experimental animals by these plants. Also alkaloids from South African plants used as medicinal plants induced liver tumours including malignant hepatocarcinoma in rats (Schoental, 1968). ${ }^{10}$ Cycads used in East Africa have been shown to contain carcinogenic factors (Muegera 1977.) ${ }^{11}$ It has been suggested that high incidence of primary liver cancer reported from South Africa might be related to the use of hepatotoxic plants in medicinal herbs as the incidence of primary liver cancer is not higher in American blacks than in whites (Schoental, 1968). ${ }^{10}$

Other herbally induced liver conditions include hepatitis (Mokhobo 1974, ${ }^{11}$ 1976) ${ }^{13}$ and liver necrosis (Wainwright and Schonland 1975). ${ }^{14}$ The plant Callilepis laureola was incriminated in the latter case. Renal failure has been reported as a consequence of widespread use of nephrotoxic traditional herbal medicine in Central Africa (Lowenthal et al., 1974; ${ }^{15}$ Dukes et al., 1969) ${ }^{16}$ and in South Africa (Buchanan and Cane, 1976). ${ }^{11}$ Among the plants incriminated are Asparagus spp, Securidaca Longepedunculata, Euphorbia matabensis spp and Crotalaria laburnifolia (Dukes et al., 1969). ${ }^{16}$ Other toxic effects reportedly associated with herbal medicine include aplastic anaemia (Lowenthal et al., 1978), ${ }^{18}$ severe penile burns caused by Cussonia Corbisien and Steganotaenia araliacea (Buchanan 1975), ${ }^{19}$ shock, hypotension, acidosis (Buchanan and Cane 1976), ${ }^{17}$ dehydration, paralytic ileus and perforation of the intestines (Solleder 1974). ${ }^{20}$

These reports stress the importance of thorough investigations into the herbals and these should include chronic toxicity tests especially with those that are to be used over a long period in the treatment of diseases like leprosy. Plants that are acutely toxic are usually recognized by the natives but those that have insidious effects that would be revealed after a latent period are unlikely to be known by those who use them.

However, these reports of toxicity should not deter investigations to foster the development of herbal medicine. Some of the principles contained in these plants may be toxic in large amounts but may prove of benefit to disease conditions when used in small amounts. This is of course true of all drugs. There are also incidences of carcinogenicity, teratogenicity, iatrogenic diseases and toxic reactions to synthetic drugs. One should therefore not discard a plant merely because it contains toxic substances or has caused poisoning when used in human. The dose used has to be taken into consideration in judging the plant.

[Addendum. Our attention has recently been drawn to three other communications which are relevant to this subject; (1) Pares Y. Inventory of African 
Higher Plants Used in Folk Medicines for Leprosy Therapy. 1 - Families Acanthaceae to Dilleniaceae. Personal communication in Leprosy Scientific Memoranda, June 1979, Memo L-1033/1, (2) Phillipson JD. Natural products as a basis for new drugs. Trends in Pharmacological Science, 1979, 1, No 2, 36, and (3) WHO. Inventory of medicinal plants; selection and characterisation. WHO Chronicle, 1979, 33, 56. Based on documents prepared for WHO on this subject, 9-13 October 1978, Geneva. Reference: unpublished WHO documents DPM/WP/78.2 and 4. Authors].

\section{References}

${ }^{1}$ Dalziel JM. The useful plants of West Tropical Africa. London: Crown Agents, 1937, $615 \mathrm{pp}$.

2 Haerdi Fritz. Die eingeborenen Heilpflanzen des Ulanga - Distrikes Tangajikas (Ostafrika). Basel: Verlag fuer Recht und Gesellschaft Ag. 1964, 278 pp.

3 Raponda-Walker A, Sillans R. Les plantes utiles $d u$ Gabon. Paris: Paul Lechevalier, $614 \mathrm{pp}$.

${ }^{4}$ Watt JM Breyer-Brandwijk MG. The medicinal and poisonous plants of Southern and Eastern Africa. Edinburgh: E \& S Livingstone, 1962, 1457 pp.

5 Tubery PR. Preparation of alcoholic extract of Lasiosiphon kraussianus. Bulletin Official de la Propriété Industrielle Francaise (IBSM) 46, 1968.

6 Goodman LS, Gilman A. The phamacological basis of therapeutics. New York: Macmillan Publishing Co., 1975, 1704 pp.

7 Schoental R. Alkaloidal constituents of Crotalaria fulva Roxb., fulvin and its N-oxide. Australian J Chem, 1963, 16 (2), 233-8.

${ }^{8}$ Schoental R. Developing world prevention or cure? Use of toxic herbs and geographic pathology. Trop geogr med, 1972, 24, 194-8.

9 Schoental R, Coady A. Hepatotoxicity of some Ethiopian and East African plants, including some used in traditional medicines. East African Medical J, 1968, 45 (8), $577-80$.

10 Schoental R. Toxicity and Carcinogenic action of pyrrolizidine alkaloids. Cancer Research, 1968, 28, 2237-46.

11 Muegera GM. Useful drugs and Cancer causing chemicals in Kenya medicinal and toxic plants. 12th Inaugural lecture, University of Nairobi p. 5-17.

12 Mokhobo KP. Acute necrodegenerative hepatitis. S Afr Med J, 1974, 48, 833.;

13 Mokhobo KP. Herb use and necrodegenerative hepatitis. $S$ Afr Med J, 1976, 50, 1096-8.

${ }^{14}$ Wain wright J, Schonland MM. Toxic liver necrosis in Zulus. S Afr Med J, 1975, 49, 1051.

15 Lowenthal MN, Jones IG, Mohelsky V. Acute renal failure in Zambian women using traditional herbal remedies. J Trop Med Hyg, 1974, 77, 190-2.

16 Dukes DC, Dukes HM, Gordon JA, Mynors JM, Weinberg RW, Davidson LAG. The toxic effects of traditional African Medicine. Centr Afr J Med, 1969, 15, 71-8.

17 Buchanan N, Cane RD. Poisoning associated with witchdoctor attendance. $S$ Afr Med J, 1976, 50, 1138.

18 Lowenthal MN, Jones IG, Desai M. Aplastic anaemia and optic fundus haemorrages due to traditional herbal remedies. J Trop Med Hyg, 1978, 81 (9), 177-9.

19 Buchanan DJ Penile burns due to application of roots Med J Zambia, 1975, 9, 42-4.

20 Solleder G. Clinical observations on toxic effects of Xhosa medicine. S Afr MedJ, 1974, 48, 2365-8. 